\title{
Pelvis Cancer pT3b TNM Finding v8
}

National Cancer Institute

\section{Source}

National Cancer Institute. Pelvis Cancer pT 36 TNM Finding v8. NCI Thesaurus. Code C136602.

Pelvis cancer with tumor spanning two pelvic segments with extraosseous extension and measuring more than $8 \mathrm{~cm}$ in greatest dimension. (from AJCC 8th Ed.) 